\title{
EVALUASI FASILITAS DAN JARAK TEMPAT PERHENTIAN KENDARAAN PENUMPANG UMUM (TPKPU) TRANS PADANG
}

\author{
HELGA YERMADONA ${ }^{1}$ \\ Fakultas Teknik, Universitas Muhammadiyah Sumatera Barat ${ }^{1}$ \\ helgayermadona@umsb.ac.id
}

\begin{abstract}
Abstrak: Koridor I Trans Padang mempunyai 73 tempat perhentian kendaraan penumpang umum (TPKPU) yaitu 45 halte dan 28 tempat pemberhentian bus (TPB) yang terdiri dari arah Imam BonjolBatas Kota sebanyak 35 unit (21 halte dan 14 TPB) dan arah Batas Kota-Imam Bonjol sebanyak 38 unit (24 halte dan 14 TPB). Di lapangan ditemukan bahwa informasi atau petunjuk jadwal kedatangan dan keberangkatan Trans Padang tidak dicantumkan di halte/TPB. Sehingga penumpang kesulitan memprediksi jadwal bus dan berapa lama waktu yang mereka perlukan untuk menunggu bus. Tujuan penelitian untuk mengevaluasi fasilitas dan jarak antar halte/TPB sesuai Keputusan Direktur Jenderal Perhubungan Darat Nomor: 271/HK.105/DRJD/96. Penelitian dilakukan dengan survey halte/TPB Trans Padang sepanjang Koridor I, kemudian mengevaluasi dan membandingkan kondisi eksisting hasil survey dengan standar yang ada. Berdasarkan analisis didapatkan hasil banyak halte/TPB yang tidak memenuhi syarat kelengkapan fasilitas. Berdasarkan jarak antar halte/TPB yang memenuhi syarat pada arah Imam Bonjol-Batas Kota sebanyak 19 halte/TPB, dan arah Batas Kota-Imam Bonjol sebanyak 19 halte/TPB.
\end{abstract}

Kata kunci: Trans Padang, halte, TPB dan Koridor I.

Abstract: In the corridor I Trans Padang, there are 73 public passenger vehicle terminals, including 45 shelters and 28 bus stops. The route from Imam Bonjol-Batas Kota has 35 units (21 shelters and 14 bus stops) and the route from Batas Kota-Imam Bonjol has 38 units (24 shelters and 14 bus stops). In the existing condition, it was found that the information or schedule instructions for Trans Padang were not included in shelter/bus stop. The passengers have difficulty predicting the bus schedule and how long to wait for the bus. The purpose of this study is to evaluate the facilities and the distance between shelter/bus stop according to Director General of Land Transportation Number 271/HK.105/DRJD/96. This research uses survey method by surveying the Trans Padang shelter/bus stop along Corridor I, evaluating and comparing the existing conditions result with standard. According to the analysis, the results are shelters/bus stop not qualified for main facilities. According to the distance between the shelters/bus stop, there are 19 qualified shelters/bus stops for the route from Imam Bonjol-Batas Kota and there are also are 19 qualified shelters/bus stops for the route from Batas Kota-Imam Bonjol.

Keywords: Trans Padang, Shelter, Bus Stop, and Koridor I.

\section{PENDAHULUAN}

\section{Latar Belakang Masalah}

Pada bulan Februari tahun 2014, kota Padang meresmikan layanan angkutan umum Bus Rapid Transit (BRT) yang dikenal dengan nama Trans Padang. Bus Trans Padang pada umumnya memiliki kapasitas 40 orang penumpang, yang terdiri dari 20 kursi untuk penumpang duduk dan 20 pegangan tangan untuk penumpang yang berdiri. Trans Padang juga dilengkapi dengan tempat duduk prioitas untuk penumpang ibu hamil, penumpang usia lanjut, dan penumpang berkebutuhan khusus. Karcis untuk menaiki Trans Padang dapat dibeli melalui petugas yang berada di dalam dengan cara pembayaran tunai atau pembayaran non tunai memakai kartu Brizzi. Tarif karcis untuk satu kali perjalanan bus Trans Padang bagi umum Rp.3500,- dan bagi pelajar Rp.1500,-.

Jumlah armada bus Trans Padang pada tahun 2017 sebanyak 20 unit yang terdiri dari 5 unit bus besar dan 15 unit bus sedang. Jumlah armada ini menurut penumpang Trans Padang masih kurang optimal. Tampak luar dan dalam bus Trans Padang dapat dilihat pada Gambar 1 berikut ini:

$40 \quad$ Fakultas Teknik UMSB

ISSN 2599-2081

EISSN 2599-2090 


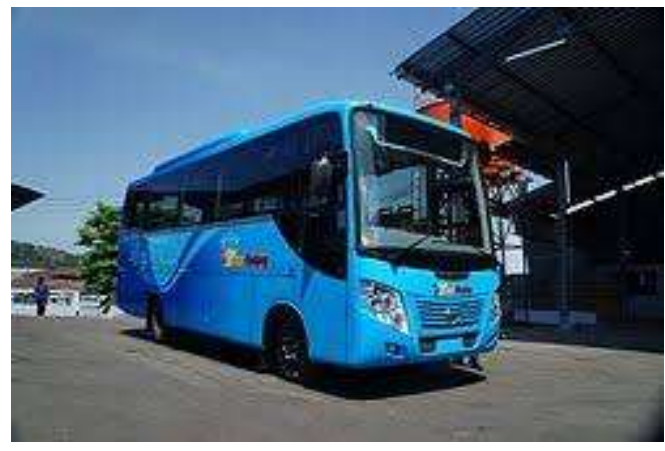

(a) Tampak luar bus

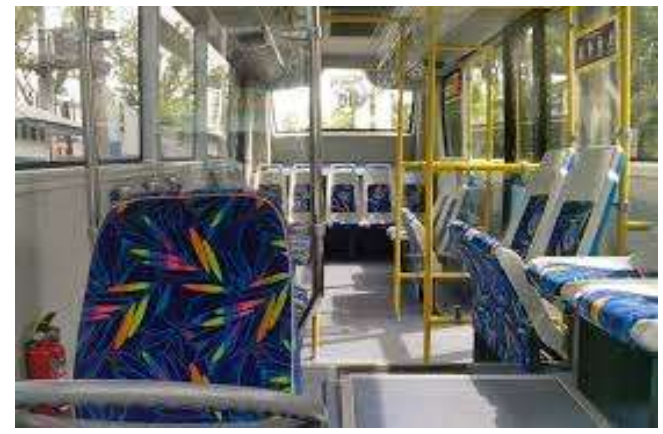

(b) Tampak dalam bus

Gambar 1. Bus Trans Padang

Sumber:https://soeloehmelajoe.wordpress.com /tag/trans-padang/

Berdasarkan survey awal di lapangan, Tempat Pemberhentian Kendaraan Penumpang Umum (TPKPU) Trans Padang berjumlah 73 unit yang terdiri dari halte dan Tempat Pemberhentian Bus (TPB) yang melayani koridor 1 sepanjang $19 \mathrm{~km}$. Koridor I ini dibagi menjadi dua arah yaitu arah Imam Bonjol - Batas Kota sebanyak 35 unit (21 halte dan 14 TPB) dan arah Batas Kota - Imam Bonjol sebanyak 38 unit (24 halte dan 14 TPB). Contoh kondisi halte dan TPB Trans Padang dapat dilihat pada Gambar 2 berikut ini:

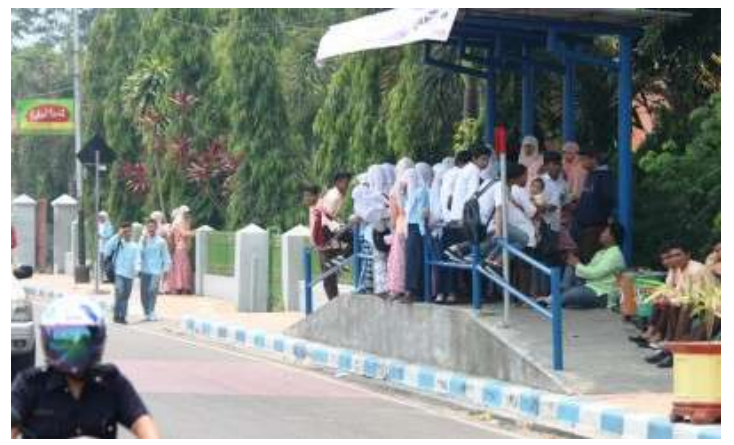

(a) Kondisi salah satu halte Trans Padang

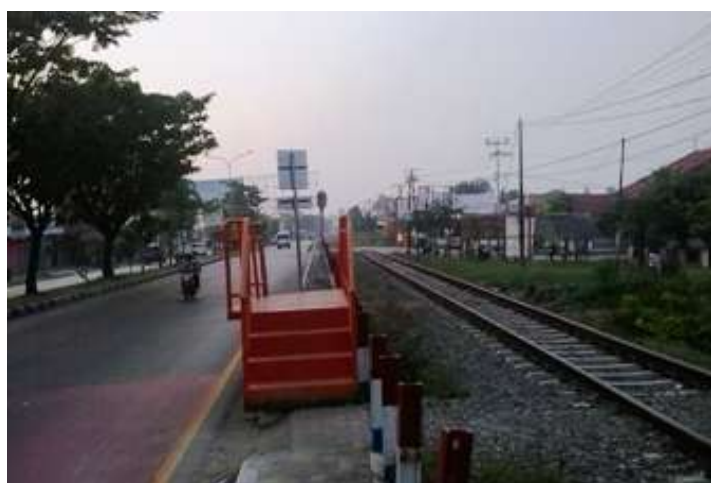

(b) Kondisi salah satu TPB Trans Padang Gambar 2. Contoh kondisi halte dan TPB Trans Padang

Sumber:https://soeloehmelajoe.wordpress.com /tag/trans-padang/

Perbedaan halte dan TPB Trans Padang dapat dilihat dari fasilitas utama yang ada. Sayangnya di lapangan, informasi atau petunjuk nama halte, info trayek angkot, jadwal kedatangan dan keberangkatan Trans Padang tidak dicantumkan di TPKPU. Sehingga penumpang kesulitan memprediksi jadwal bus dan berapa lama waktu yang mereka perlukan untuk menunggu bus di TPKPU. Umumnya penumpang Trans Padang masih belum bisa membedakan halte dengan TPB. Penumpang masih menganggap semua tempat pemberhentian bus Trans Padang adalah halte. TPKPU sebagai fasilitas penumpang menunggu bus, dan tempat menaikkan dan menurunkan penumpang diperlukan suatu kajian terhadap pengaturan prasarana atau fasilitas TPKPU yang sesuai dengan kebutuhan dan jarak antar halte atau TPB yang pemanfaatannya terjangkau secara maksimal oleh masyarakat umum.

Menurut penelitian $\mathrm{R}$ Nurjanah, dkk (2015), diketahui bahwa load factor Trans Padang padat $(>1)$ pada hari kerja saat jam sibuk pagi dan jam sibuk sore rute Pasar RayaBatas Kota. Pada hari libur, load factor bus Trans Padang tidak padat $(<1)$. Padatnya load factor tersebut tentu harus diiringi dengan kelengkapan fasilitas tempat pemberhentian kendaraan penumpang umum (TPKPU) yang memadai bagi penumpang. Sehingga perlu dianalisa fasilitas dan jarak antar TPKPU Trans Padang. 


\section{Tujuan Penelitian}

$\begin{array}{lcr}\begin{array}{c}\text { Penelitian ini bertujuan } \\ \text { untuk }\end{array} \\ \text { mengevaluasi fasilitas utama } & \text { tempat } \\ \text { pemberhentian kendaraan umum } & \text { (TPKPU) } \\ \text { Trans Padang yang terdiri dari halte dan TPB. } \\ \text { Serta mengetahui jarak TPKPU antar halte dan } \\ \text { TPB Trans Padang apakah sudah sesuai } \\ \text { dengan Keputusan Direktur Jenderal } \\ \text { Perhubungan } & \text { Darat } & \text { Nomor: } \\ \text { 271/HK.105/DRJD/96. } & \end{array}$

\section{TINJAUAN PUSTAKA}

Berdasarkan Peraturan Menteri Perhubungan Republik Indonesia Nomor PM 10 tahun 2012 pasal 1 ayat 8 dan 9, yang dimaksud dengan halte adalah tempat pemberhentian kendaraan bermotor umum untuk menaikkan dan menurunkan penumpang dan fasilitas pendukung seperti fasilitas pejalan kaki menuju halte yang berupa trotoar, tempat penyebrangan yang dinyatakan dengan marka jalan dan/atau rambu lalu lintas, jembatan penyebrangan dan/atau terowongan. Tempat pemberhentian kendaraan penumpang umum (TPKPU) terdiri dari halte dan tempat pemberhentian bus (TPB). TPB adalah tempat pemberhentian bus (bus stop) untuk menurunkan dan/atau menaikkan penumpang.

Perbedaan fasilitas utama TPKPU antara halte dan TPB dapat dilihat pada Tabel 1 berikut ini:

Tabel 1. Fasilitas Utama TPKPU (halte dan $\mathrm{TPB})$

\begin{tabular}{|c|c|}
\hline Halte & TPB \\
\hline $\begin{array}{l}\text { 1. Identitas halte } \\
\text { berupa nama } \\
\text { dan/atau nomor. } \\
\text { 2. Rambu petunjuk } \\
\text { 3. Papan informasi } \\
\text { trayek } \\
\text { 4. Lampu } \\
\text { penerangan } \\
\text { 5. Tempat duduk }\end{array}$ & $\begin{array}{ll}\text { 1. } & \text { Rambu petunjuk } \\
\text { 2. Papan informasi } \\
\text { trayek }\end{array}$ \\
\hline
\end{tabular}

Sumber: Asmara, A.A.(2016)

Fasilitas tambahan berupa: telpon umum, tempat sampah, pagar, dan papan iklan/pengumuman.

Menurut Keputusan Direktur Jenderal Perhubungan Darat Nomor:
271/HK.105/DRJD/96, penentuan jarak antar halte dan/atau TPB dapat dilihat pada Tabel 2 berikut:

Tabel 2. Jarak antar halte dan/atau TPB

\begin{tabular}{|c|l|l|l|}
\hline Zona & \multicolumn{1}{|c|}{$\begin{array}{c}\text { Tata Guna } \\
\text { Lahan }\end{array}$} & Lokasi & $\begin{array}{c}\text { Jarak } \\
\text { Tempat } \\
\text { Henti } \\
(\mathbf{m})\end{array}$ \\
\hline 1 & $\begin{array}{l}\text { Pusat kegiatan } \\
\text { sangat padat, } \\
\text { pertokoan }\end{array}$ & $\begin{array}{l}\text { CBD, } \\
\text { Kota }\end{array}$ & $\begin{array}{l}200-300 \\
*)\end{array}$ \\
\hline 2 & $\begin{array}{l}\text { Padat: } \\
\text { perkantoran, } \\
\text { sekolah, jasa }\end{array}$ & Kota & $300-400$ \\
\hline 3 & Permukiman & Kota & $300-400$ \\
\hline 4 & $\begin{array}{l}\text { Campuran } \\
\text { padat: } \\
\text { perumahan, } \\
\text { sekolah, jasa }\end{array}$ & Pinggiran & $300-500$ \\
\hline 5 & $\begin{array}{l}\text { Campuran } \\
\text { jarang: } \\
\text { perumahan, } \\
\text { lading, sawah, } \\
\text { tanah kosong }\end{array}$ & Pinggiran & $500-$ \\
1000 \\
\hline
\end{tabular}

Keterangan: *)jarak 200m dipakai bila sangat diperlukan saja, sedangkan jarak umumnya $300 \mathrm{~m}$.

Sumber: Departemen Perhubungan (1996)

Tempat perhentian harus tepat penempatannya agar tidak mengganggu lalu lintas (Kepdirjen Darat No SK.687/AJ.206/DRJD/2002). Menurut Departemen Perhubungan (1996), tata letak halte dan/atau TPB terhadap ruang lalu lintas seperti berikut:

1. Jarak maksimal terhadap fasilitas peyeberangan pejalan kaki.

2. Jarak minimal halte dari persimpangan adalah $50 \mathrm{~m}$ atau bergantung pada Panjang antrean.

3. Jarak minimal Gedung (seperti rumah sakit, tempat ibadah) yang membutuhkan ketenangan adalah 100 meter.

4. Peletakan di persimpangan menganut sistem campuran yaitu antara sesudah persimpangan (farside) dan sebelum persimpangan (nearside), seperti pada Gambar 3 dan 4 berikut: 


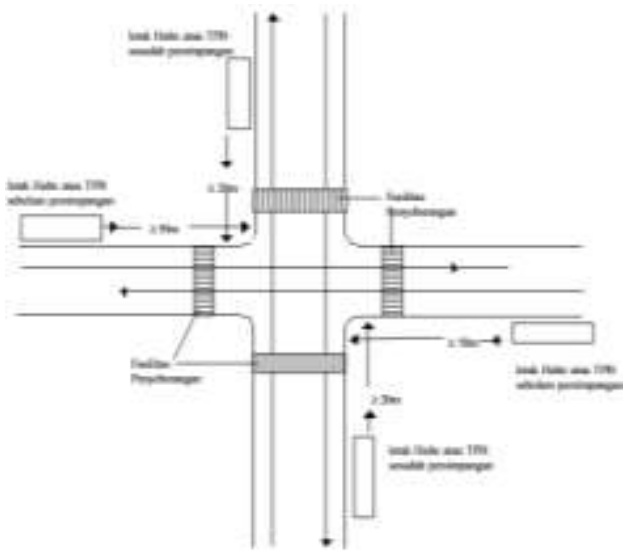

Gambar 3. Peletakan tempat perhentian di pertemuan jalan simpang empat

Sumber: Departemen Perhubungan (1996)

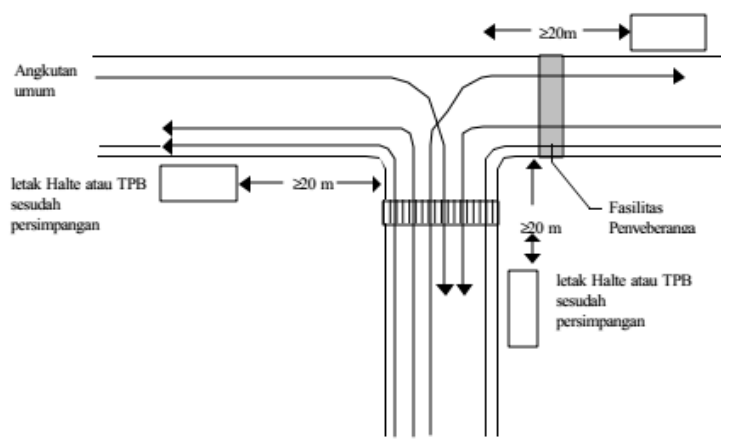

Gambar 4. Peletakan tempat perhentian di pertemuan jalan simpang tiga

Sumber: Departemen Perhubungan (1996)

5. Peletakan di ruas jalan terlihat pada Gambar 5 dan 6 berikut:

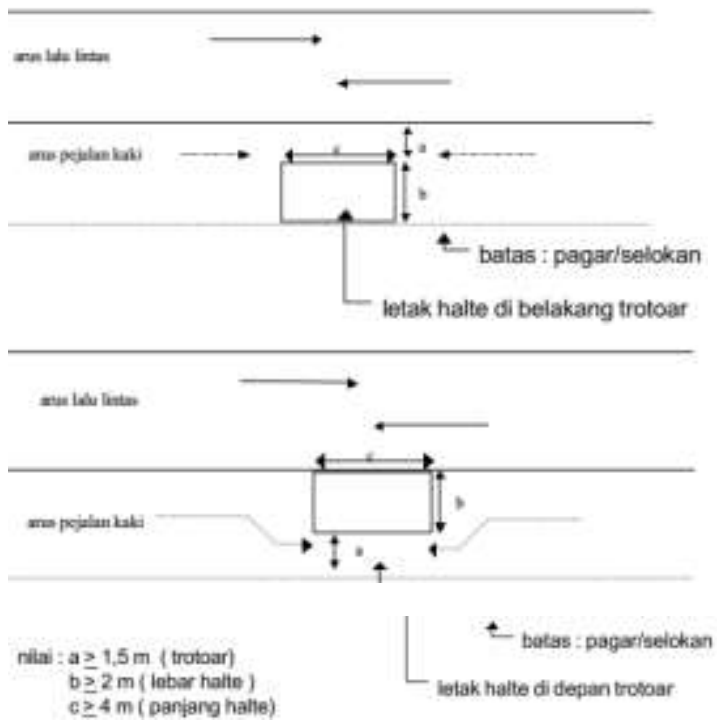

Gambar 5. Tata letak halte pada ruas jalan Sumber: Departemen Perhubungan (1996)

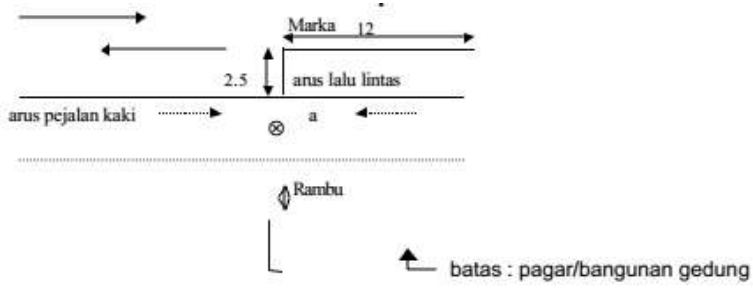

nilai $\mathrm{a}=\min .0 .60 \mathrm{~m}$ dari bagian tepi paling luar bahu jalan

Gambar 6. Tata letak TPB pada ruas jalan Sumber: Departemen Perhubungan (1996)

\section{METODE PENELITIAN}

Metode penelitian terbagi atas beberapa tahapan:

1. Studi pendahuluan

Mengumpulkan literatur dan jurnal penelitian terdahulu yang membahas halte bus Trans khususnya Trans Padang.

2. Pemilihan lokasi penelitian

Lokasi penelitian dilakukan sepanjang Koridor I rute bus Trans Padang sebanyak 71 unit TPKPU yang terdiri dari arah Imam Bonjol - Batas Kota sebanyak 35 unit (21 halte dan 14 TPB) dan arah Batas Kota - Imam Bonjol sebanyak 36 unit (24 halte dan 12 TPB).

3. Penentuan periode survey Survey dilakukan bersamaan dengan jam operasional bus Trans Padang yaitu jam 06.00 sampai 20.00 WIB.

4. Peralatan yang digunakan
a. Formulir survey
b. Alat tulis
c. GPS dan google maps

5. Pengumpulan data, data primer diperoleh dari hasil survey fasilitas TPKPU dan jarak antar halte /TPB disepanjang Koridor I Trans Padang, sedangkan data sekunder diperoleh dari instansi terkait (UPT Trans Padang)

6. Analisa data

Analisa data dilakukan dengan cara mengevaluasi hasil survey di lapangan dibandingkan dengan Keputusan Direktur Jenderal Perhubungan Darat Nomor: 271/HK.105/DRJD/96.

\section{HASIL DAN PEMBAHASAN}

Lokasi halte dan TPB sepanjang Koridor I Trans Padang dapat dilihat pada Tabel 3 berikut ini: 
Tabel 3. Lokasi halte dan TPB Trans Padang

\begin{tabular}{|c|c|c|c|}
\hline \multicolumn{2}{|c|}{$\begin{array}{c}\text { Arah Imam Bonjol } \\
\text { - Batas Kota }\end{array}$} & \multicolumn{2}{|c|}{$\begin{array}{l}\text { Arah Batas Kota - } \\
\text { Imam Bonjol }\end{array}$} \\
\hline 1 & $\begin{array}{l}\text { Halte Imam } \\
\text { Bonjol }\end{array}$ & 36 & $\begin{array}{l}\text { Halte Seberang } \\
\text { Simpang Mega } \\
\text { Permai I }\end{array}$ \\
\hline 2 & $\begin{array}{l}\text { Halte Kantor } \\
\text { Pos }\end{array}$ & 37 & $\begin{array}{l}\text { TPB Padang } \\
\text { Sarai }\end{array}$ \\
\hline 3 & $\begin{array}{l}\text { Halte SMPN } 1 \\
\text { Padang }\end{array}$ & 38 & $\begin{array}{l}\text { TPB Kayu Kalek } \\
\text { II }\end{array}$ \\
\hline 4 & $\begin{array}{l}\text { Halte SMK } \\
\text { Nasional }\end{array}$ & 39 & $\begin{array}{l}\text { Halte Kampus II } \\
\text { UNP Lubuk } \\
\text { Buaya }\end{array}$ \\
\hline 5 & $\begin{array}{l}\text { Halte Lapangan } \\
\text { Tenis Korem }\end{array}$ & 40 & $\begin{array}{l}\text { TPB SMPN } 15 \\
\text { Lubuk Buaya }\end{array}$ \\
\hline 6 & $\begin{array}{l}\text { Halte Kantor } \\
\text { Gubernur }\end{array}$ & 41 & $\begin{array}{l}\text { TPB Monang } \\
\text { (Depan Kantor } \\
\text { Camat) }\end{array}$ \\
\hline 7 & $\begin{array}{l}\text { TPB Dinas } \\
\text { Tenaga Kerja }\end{array}$ & 42 & $\begin{array}{l}\text { TPB Mesjid } \\
\text { Darul Islah }\end{array}$ \\
\hline 8 & $\begin{array}{l}\text { Halte KONI } \\
\text { (GOR Haji Agus } \\
\text { Salim) }\end{array}$ & 43 & $\begin{array}{l}\text { TPB Seb } \\
\text { Jembatan } \\
\text { Timbang Lubuk } \\
\text { Buaya }\end{array}$ \\
\hline 9 & $\begin{array}{l}\text { TPB Bank } \\
\text { Nagari }\end{array}$ & 44 & $\begin{array}{l}\text { Halte Gedung } \\
\text { Pemuda OPEL } \\
\text { Lubuk Buaya }\end{array}$ \\
\hline 10 & $\begin{array}{l}\text { Halte Stikes } \\
\text { Indonesia }\end{array}$ & 45 & $\begin{array}{l}\text { Halte Seb Suzuki } \\
\text { Lubuk Buaya }\end{array}$ \\
\hline 11 & $\begin{array}{l}\text { Halte BPTN } \\
\text { (Belanti) }\end{array}$ & 46 & $\begin{array}{l}\text { TPB Simpang } \\
\text { Kalumpang }\end{array}$ \\
\hline 12 & Halte AKBP & 47 & $\begin{array}{l}\text { Halte Masjid Al- } \\
\text { Ikram }\end{array}$ \\
\hline 13 & TPB RS Jantung & 48 & $\begin{array}{l}\text { Halte Mesjid } \\
\text { Nailus Sa'dah }\end{array}$ \\
\hline 14 & $\begin{array}{l}\text { Halte Elang } \\
\text { Perkasa }\end{array}$ & 49 & $\begin{array}{l}\text { TPB SEb Perum } \\
\text { Singgalang }\end{array}$ \\
\hline 15 & Halte DPRD I & 50 & $\begin{array}{l}\text { TPB Samping } \\
\text { Star Wash }\end{array}$ \\
\hline
\end{tabular}

\begin{tabular}{|c|c|c|c|}
\hline \multicolumn{2}{|c|}{$\begin{array}{c}\text { Arah Imam Bonjol } \\
\text { - Batas Kota }\end{array}$} & \multicolumn{2}{|c|}{$\begin{array}{l}\text { Arah Batas Kota - } \\
\text { Imam Bonjol }\end{array}$} \\
\hline 16 & $\begin{array}{l}\text { TPB Simpang } \\
\text { Labor }\end{array}$ & 51 & $\begin{array}{l}\text { TPB Rumah } \\
\text { Makan Surya } \\
\text { (Seb Stasiun } \\
\text { Tabing) }\end{array}$ \\
\hline 17 & Halte UNP & 52 & $\begin{array}{l}\text { Halte Asia } \\
\text { Biskuit } 2\end{array}$ \\
\hline 18 & Halte Capella & 53 & $\begin{array}{l}\text { Halte Seberang } \\
\text { Asrama Haji }\end{array}$ \\
\hline 19 & $\begin{array}{l}\text { TPB Hotel Son } \\
\& \text { Sons }\end{array}$ & 54 & $\begin{array}{l}\text { Halte Simpang } \\
\text { GIA }\end{array}$ \\
\hline 20 & $\begin{array}{l}\text { TPB Asrama } \\
\text { Haji }\end{array}$ & 55 & $\begin{array}{l}\text { Halte Simpang } \\
\text { Tunggul Hitam }\end{array}$ \\
\hline 21 & $\begin{array}{l}\text { Halte Asia } \\
\text { Biskuit } 1\end{array}$ & 56 & $\begin{array}{l}\text { TPB Seberang } \\
\text { UNP }\end{array}$ \\
\hline 22 & $\begin{array}{l}\text { Halte Stasiun } \\
\text { Tabing }\end{array}$ & 57 & $\begin{array}{l}\text { Halte Taman } \\
\text { Bingkuang } \\
\text { (Basko) }\end{array}$ \\
\hline 23 & $\begin{array}{l}\text { Halte Muaro } \\
\text { Panjalinan }\end{array}$ & 58 & Halte DPRD 2 \\
\hline 24 & $\begin{array}{l}\text { TPB Perum } \\
\text { Singgalang }\end{array}$ & 59 & Halte Al-Azhar \\
\hline 25 & $\begin{array}{l}\text { TPB Ruko Griya } \\
\text { Bunga Mas }\end{array}$ & 60 & $\begin{array}{l}\text { TPB Trans Mart } \\
\text { Padang }\end{array}$ \\
\hline 26 & $\begin{array}{l}\text { TPB RS } \\
\text { Bersalin Tiara } \\
\text { Anggrek }\end{array}$ & 61 & $\begin{array}{l}\text { Halte Stikes } \\
\text { Alifah (Seb } \\
\text { AKBP) }\end{array}$ \\
\hline 27 & $\begin{array}{l}\text { TPB Seb Af } \\
\text { Skotang }\end{array}$ & 62 & $\begin{array}{l}\text { Halte Seb BTPN } \\
\text { (Belanti) }\end{array}$ \\
\hline 28 & $\begin{array}{l}\text { Halte Seb } \\
\text { Simpang } \\
\text { Kalumpang }\end{array}$ & 63 & $\begin{array}{l}\text { Halte Masjid } \\
\text { Raya Sumbar }\end{array}$ \\
\hline 29 & $\begin{array}{l}\text { TPB Pasar } \\
\text { Lubuk Buaya }\end{array}$ & 64 & $\begin{array}{l}\text { Halte Telkom } \\
\text { Padang Baru }\end{array}$ \\
\hline 30 & $\begin{array}{l}\text { TPB Adinegoro } \\
\text { Swalayan }\end{array}$ & 65 & $\begin{array}{l}\text { Halte Seb GOR } \\
\text { Haji Agus Salim }\end{array}$ \\
\hline 31 & $\begin{array}{l}\text { TPB Seb Masjid } \\
\text { Darul Islah }\end{array}$ & 66 & $\begin{array}{l}\text { Halte LBA LIA } \\
\text { (Bank BTN) }\end{array}$ \\
\hline
\end{tabular}

ISSN 2599-2081

EISSN 2599-2090 


\begin{tabular}{|c|l|c|l|}
\hline \multicolumn{2}{|c|}{$\begin{array}{c}\text { Arah Imam Bonjol } \\
- \text { Batas Kota }\end{array}$} & \multicolumn{2}{c|}{$\begin{array}{l}\text { Arah Batas Kota - } \\
\text { Imam Bonjol }\end{array}$} \\
\hline 32 & $\begin{array}{l}\text { Halte Polsek } \\
\text { Koto Tangah }\end{array}$ & 67 & $\begin{array}{l}\text { Halte TK Yos } \\
\text { Sudarso }\end{array}$ \\
\hline 33 & $\begin{array}{l}\text { Halte Seberang } \\
\text { Kampus II UNP } \\
\text { Lubuk Buaya }\end{array}$ & 68 & $\begin{array}{l}\text { Halte Graha Asri } \\
\text { (Seb Korem) }\end{array}$ \\
\hline 34 & $\begin{array}{l}\text { TPB Plasa } \\
\text { Telkom Padang } \\
\text { Sarai }\end{array}$ & 69 & $\begin{array}{l}\text { Halte Bank } \\
\text { CIMB Niaga } \\
\text { (RRI) }\end{array}$ \\
\hline 35 & $\begin{array}{l}\text { Halte Simp } \\
\text { Mega Permai }\end{array}$ & 70 & $\begin{array}{l}\text { Halte SMPN 1 } \\
\text { Padang }\end{array}$ \\
\cline { 3 - 4 } & 71 & $\begin{array}{l}\text { Halte Hotel } \\
\text { Padang }\end{array}$ \\
\cline { 3 - 4 } & 72 & TPB Pasar Raya \\
\cline { 3 - 4 } & 73 & $\begin{array}{l}\text { TPB Mesjid } \\
\text { Nurul Iman }\end{array}$ \\
\hline
\end{tabular}

Berdasarkan lokasi halte/TPB pada tabel di atas terdapat 73 TPKPU (45 halte dan 28 TPB) yang terdiri dari arah Imam Bonjol-Batas Kota sebanyak 35 unit (21 halte dan 14 TPB) dan arah Batas Kota-Imam Bonjol sebanyak 38 unit (24 halte dan 14 TPB). Kemudian dilakukan evaluasi perbandingan fasilitas kondisi eksisting dengan Keputusan Direktur Jenderal Perhubungan Darat Nomor: 271/HK.105/DRJD/96, hasilnya dapat dilihat pada Gambar 7 dan 8 berikut:

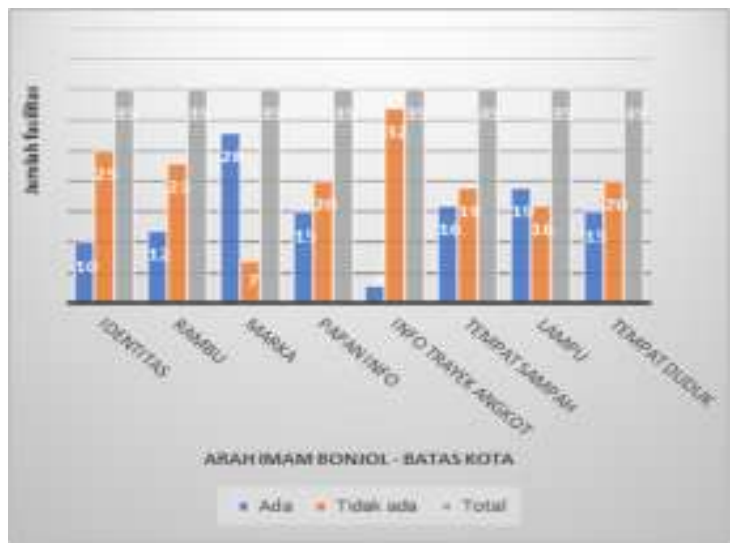

Gambar 7. Fasilitas halte/TPB Trans Padang Arah Imam Bonjol-Batas Kota
Dari Gambar 7 dapat disimpulkan untuk fasilitas halte/TPB Trans Padang arah Imam Bonjol-Batas Kota terdapat 10 halte yang mempunyai identitas, 12 halte/TPB dilengkapi dengan rambu, 28 halte dilengkapi marka, 15 halte dilengkapi papan info, 3 halte yang dilengkapi info trayek angkot, 16 halte yang dilengkapi tempat sampah, 19 halte dilengkapi lampu, dan hanya 15 halte yang dilengkapi tempat duduk.

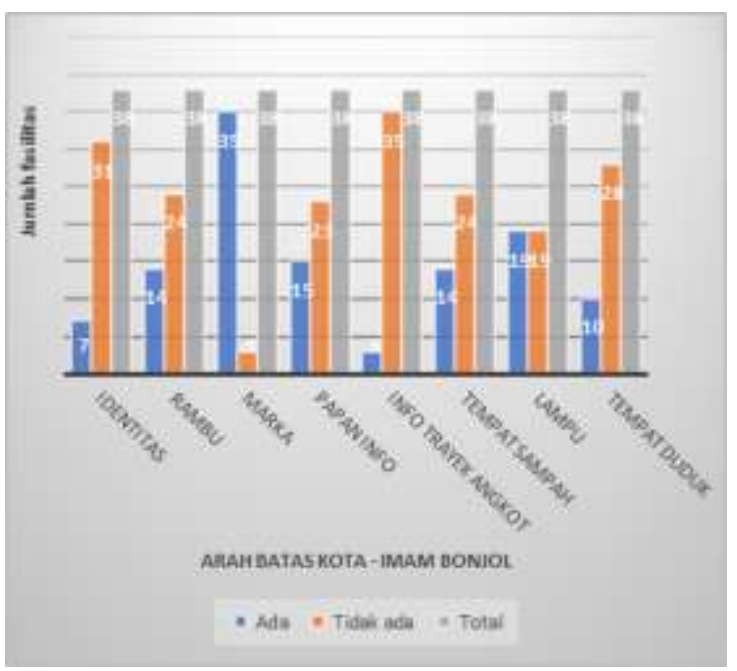

Gambar 8. Fasilitas halte/TPB Trans Padang Arah Batas Kota- Imam Bonjol

Dari Gambar 8 dapat disimpulkan untuk fasilitas halte/TPB Trans Padang arah Batas Kota- Imam Bonjol terdapat 7 halte yang mempunyai identitas, 14 halte/TPB dilengkapi dengan rambu, 35 halte/TPB dilengkapi marka, 15 halte dilengkapi papan info, 3 halte dilengkapi info trayek angkot, 14 halte yang dilengkapi tempat sampah, 19 halte dilengkapi lampu, dan hanya 10 halte yang dilengkapi tempat duduk.

Evaluasi jarak antar halte/TPB kondisi eksisting dengan Keputusan Direktur Jenderal Perhubungan Darat Nomor: 271/HK.105/DRJD/96 dapat dilihat pada Tabel 4 dan 5 berikut: 
Tabel 4. Jarak antar halte/TPB arah Imam Bonjol-Batas Kota

\begin{tabular}{|c|c|c|c|}
\hline \multirow[t]{2}{*}{$\begin{array}{c}\text { No } \\
\text { Halte/T } \\
\text { PB }\end{array}$} & \multicolumn{2}{|c|}{$\begin{array}{c}\text { Jarak antar } \\
\text { halte/TPB (m) } \\
\text { arah Imam } \\
\text { Bonjol-Batas Kota }\end{array}$} & \multirow{2}{*}{$\begin{array}{c}\% \\
\text { Ketercapai } \\
\text { an Standar }\end{array}$} \\
\hline & Standar & $\begin{array}{c}\text { Eksistin } \\
\text { g }\end{array}$ & \\
\hline $1-2$ & $200-300$ & \pm 300 & 100 \\
\hline $2-3$ & $200-300$ & \pm 300 & 100 \\
\hline $3-4$ & $200-300$ & \pm 500 & 100 \\
\hline $4-5$ & $300-400$ & \pm 400 & 100 \\
\hline $5-6$ & $300-400$ & \pm 400 & 100 \\
\hline $6-7$ & $300-400$ & \pm 400 & 100 \\
\hline $7-8$ & $300-400$ & \pm 400 & 100 \\
\hline $8-9$ & $300-400$ & \pm 200 & 100 \\
\hline $9-10$ & $300-400$ & \pm 600 & 66,67 \\
\hline $10-11$ & $300-400$ & \pm 400 & 100 \\
\hline $11-12$ & $300-400$ & \pm 500 & 80 \\
\hline $12-13$ & $300-400$ & \pm 300 & 100 \\
\hline $13-14$ & $300-400$ & \pm 300 & 100 \\
\hline $14-15$ & $300-400$ & \pm 500 & 80 \\
\hline $15-16$ & $300-400$ & \pm 800 & 50 \\
\hline $16-17$ & $300-400$ & \pm 400 & 100 \\
\hline $17-18$ & $300-400$ & \pm 600 & 66,67 \\
\hline $18-19$ & $300-400$ & \pm 800 & 50 \\
\hline $19-20$ & $300-400$ & \pm 800 & 50 \\
\hline $20-21$ & $300-400$ & \pm 700 & 57,14 \\
\hline $21-22$ & $300-400$ & \pm 700 & 57,14 \\
\hline $22-23$ & $300-400$ & \pm 700 & 57,14 \\
\hline $23-24$ & $300-400$ & \pm 400 & 100 \\
\hline
\end{tabular}

\begin{tabular}{|c|c|c|c|}
\hline $\begin{array}{c}\text { No } \\
\text { Halte/T } \\
\text { PB }\end{array}$ & \multicolumn{2}{|c|}{$\begin{array}{c}\text { Jarak antar } \\
\text { halte/TPB (m) } \\
\text { arah Imam } \\
\text { Bonjol-Batas Kota }\end{array}$} & $\begin{array}{c}\text { \% } \\
\text { Ketercapai } \\
\text { an Standar }\end{array}$ \\
\cline { 2 - 4 } & Standar & $\begin{array}{c}\text { Eksistin } \\
\text { g }\end{array}$ & \\
\hline $24-25$ & $300-400$ & \pm 600 & 66,67 \\
\hline $25-26$ & $300-400$ & \pm 500 & 80 \\
\hline $26-27$ & $300-400$ & \pm 900 & 44,44 \\
\hline $27-28$ & $300-400$ & \pm 800 & 50 \\
\hline $28-29$ & $300-400$ & \pm 500 & 80 \\
\hline $29-30$ & $300-400$ & \pm 600 & 66,67 \\
\hline $30-31$ & $300-400$ & \pm 400 & 100 \\
\hline $31-32$ & $300-400$ & \pm 400 & 100 \\
\hline $32-33$ & $300-400$ & \pm 400 & 100 \\
\hline $33-34$ & $300-400$ & \pm 100 & 100 \\
\hline $34-35$ & $300-400$ & \pm 100 & 100 \\
\hline$D 21$ & & \\
\hline
\end{tabular}

Dari hasil evaluasi jarak antar halte/TPB pada Tabel 4 di atas, sebanyak 35 halte/TPB arah Imam Bonjol-Batas kota yang memenuhi $100 \%$ kriteria standar Keputusan Direktur Jenderal Perhubungan Darat Nomor: 271/HK.105/DRJD/96 hanya ada 19 halte/TPB, sisanya sebanyak 16 halte/TPB tidak memenuhi standar jarak.

Tabel 5. Jarak antar halte/TPB arah Batas Kota-Imam Bonjol

\begin{tabular}{|l|c|c|c|}
\hline $\begin{array}{l}\text { No } \\
\text { Halte/T } \\
\text { PB }\end{array}$ & \multicolumn{2}{|c|}{$\begin{array}{c}\text { Jarak antar } \\
\text { halte/TPB (m) } \\
\text { arah Imam } \\
\text { Bonjol-Batas Kota }\end{array}$} & $\begin{array}{c}\text { \% } \\
\text { Ketercapai } \\
\text { an Standar }\end{array}$ \\
\cline { 2 - 4 } & Standar & $\begin{array}{c}\text { Eksistin } \\
\text { g }\end{array}$ & \\
\hline $36-37$ & $300-400$ & \pm 150 & 100 \\
\hline $37-38$ & $300-400$ & \pm 100 & 100 \\
\hline $38-39$ & $300-400$ & \pm 100 & 100 \\
\hline $39-40$ & $300-400$ & \pm 400 & 100 \\
\hline
\end{tabular}




\begin{tabular}{|c|c|c|c|}
\hline \multirow[t]{2}{*}{$\begin{array}{l}\text { No } \\
\text { Halte/T } \\
\text { PB }\end{array}$} & \multicolumn{2}{|c|}{$\begin{array}{c}\text { Jarak antar } \\
\text { halte/TPB (m) } \\
\text { arah Imam } \\
\text { Bonjol-Batas Kota }\end{array}$} & \multirow{2}{*}{$\begin{array}{c}\% \\
\text { Ketercapai } \\
\text { an Standar }\end{array}$} \\
\hline & Standar & $\begin{array}{c}\text { Eksistin } \\
\mathrm{g}\end{array}$ & \\
\hline $40-41$ & $300-400$ & \pm 600 & 66,67 \\
\hline $41-42$ & $300-400$ & \pm 500 & 80 \\
\hline $42-43$ & $300-400$ & \pm 300 & 100 \\
\hline $43-44$ & $300-400$ & \pm 500 & 80 \\
\hline $44-45$ & $300-400$ & \pm 300 & 100 \\
\hline $45-46$ & $300-400$ & \pm 500 & 80 \\
\hline $46-47$ & $300-400$ & \pm 800 & 50 \\
\hline $47-48$ & $300-400$ & \pm 400 & 100 \\
\hline $48-49$ & $300-400$ & \pm 400 & 100 \\
\hline $49-50$ & $300-400$ & \pm 400 & 100 \\
\hline $50-51$ & $300-400$ & \pm 1000 & 40 \\
\hline $51-52$ & $300-400$ & \pm 600 & 66,67 \\
\hline $52-53$ & $300-400$ & \pm 700 & 57,14 \\
\hline $53-54$ & $300-400$ & \pm 800 & 50 \\
\hline $54-55$ & $300-400$ & \pm 800 & 50 \\
\hline $55-56$ & $300-400$ & \pm 600 & 66,67 \\
\hline $56-57$ & $300-400$ & \pm 400 & 100 \\
\hline $57-58$ & $300-400$ & \pm 800 & 50 \\
\hline $58-59$ & $300-400$ & \pm 500 & 80 \\
\hline $59-60$ & $300-400$ & \pm 400 & 100 \\
\hline $60-61$ & $300-400$ & \pm 200 & 100 \\
\hline $61-62$ & $300-400$ & \pm 400 & 100 \\
\hline $62-63$ & $300-400$ & \pm 600 & 66,67 \\
\hline $63-64$ & $300-400$ & \pm 300 & 100 \\
\hline
\end{tabular}

\begin{tabular}{|l|c|c|c|}
\hline $\begin{array}{l}\text { No } \\
\text { Halte/T } \\
\text { PB }\end{array}$ & \multicolumn{2}{|c|}{$\begin{array}{c}\text { Jarak antar } \\
\text { halte/TPB (m) } \\
\text { arah Imam } \\
\text { Bonjol-Batas Kota }\end{array}$} & $\begin{array}{c}\text { \% } \\
\text { Ketercapai } \\
\text { an Standar }\end{array}$ \\
\cline { 2 - 4 } & Standar & $\begin{array}{c}\text { Eksistin } \\
\text { g }\end{array}$ & \\
\hline $64-65$ & $300-400$ & \pm 300 & 100 \\
\hline $65-66$ & $300-400$ & \pm 400 & 100 \\
\hline $66-67$ & $300-400$ & \pm 500 & 80 \\
\hline $67-68$ & $200-300$ & \pm 400 & 100 \\
\hline $68-69$ & $200-300$ & \pm 500 & 80 \\
\hline $69-70$ & $200-300$ & \pm 200 & 100 \\
\hline $70-71$ & $200-300$ & \pm 300 & 100 \\
\hline $71-72$ & $200-300$ & \pm 500 & 60 \\
\hline $72-73$ & $200-300$ & \pm 500 & 60 \\
\hline
\end{tabular}

Dari hasil evaluasi jarak antar halte/TPB pada Tabel 5 di atas, sebanyak 38 halte/TPB arah Batas Kota-Imam Bonjol yang memenuhi $100 \%$ kriteria standar Keputusan Direktur Jenderal Perhubungan Darat Nomor: 271/HK.105/DRJD/96 hanya 19 halte/TPB, sisanya 19 halte/TPB tidak memenuhi syarat jarak. Untuk halte/TPB yang tidak memenuhi standar jarak maka perlu adanya penambahan halte/TPB sesuai lokasi peruntukan berdasarkan kriteria yang ada.

\section{SIMPULAN}

Berdasarkan hasil dan analisa penelitian di atas dapat diambil kesimpulan sebagai berikut:

1. Pada Koridor I rute bus Trans Padang terdapat 73 unit TPKPU yang terdiri dari 45 halte dan 28 TPB. Arah Imam Bonjol Batas Kota sebanyak 35 unit (21 halte dan 14 TPB) dan arah Batas Kota - Imam Bonjol sebanyak 38 unit (24 halte dan 14 TPB).

2. Hasil survey menunjukkan arah Imam Bonjol-Batas Kota terdapat 10 halte yang mempunyai identitas, 12 halte/TPB dilengkapi dengan rambu, 28 halte dilengkapi marka, 15 halte dilengkapi papan info, 3 halte yang dilengkapi info 
trayek angkot, 16 halte yang dilengkapi tempat sampah, 19 halte dilengkapi lampu, dan hanya 15 halte yang dilengkapi tempat duduk.

3. Untuk arah Batas Kota-Imam Bonjol terdapat 7 halte yang mempunyai identitas, 14 halte/TPB dilengkapi dengan rambu, 35 halte/TPB dilengkapi marka, 15 halte dilengkapi papan info, 3 halte dilengkapi info trayek angkot, 14 halte yang dilengkapi tempat sampah, 19 halte dilengkapi lampu, dan hanya 10 halte yang dilengkapi tempat duduk.

4. Hasil evaluasi jarak antar halte/TPB Trans Padang sebanyak 35 halte/TPB arah Imam Bonjol-Batas kota yang memenuhi $100 \%$ kriteria standar Keputusan Direktur Jenderal Perhubungan Darat Nomor: 271/HK.105/DRJD/96 hanya ada 19 halte/TPB, sisanya sebanyak 16 halte/TPB tidak memenuhi standar jarak.

5. Sedangkan 38 halte/TPB arah Batas KotaImam Bonjol yang memenuhi $100 \%$ kriteria standar Keputusan Direktur Jenderal Perhubungan Darat Nomor: 271/HK.105/DRJD/96 hanya 19 halte/TPB, sisanya sebanyak 19 halte/TPB tidak memenuhi standar jarak.

\section{UCAPAN TERIMAKASIH}

Ucapan terima kasih kepada semua pihak yang telah membantu penelitian ini, terutama kepada M. Fashli Utama Mufti sebagai tim suryeyor.

\section{DAFTAR PUSTAKA}

Asmara, A. G. (2016) Evaluasi Kinerja Halte Bus Dalam Upaya Meningkatkan Pelayanan Bus Trans Sarbagita, Bali. Universitas Udayana.

Astri Mutia Ekasari (2014) 'Evaluasi Rute dan Halte Bus di Kota Bandung', Perencanaan Wilayah dan Kota, 15(1), pp. 42-49.

Dephub (1996) Pedoman Teknis Perekayasanaan Tempat Perhentian Kendaraan Penumpang Umum. Jakarta: Direktur Jenderal Perhubungan Darat.

Kami, B. H. (2006) 'Evaluasi Fungsi Halte Sebagai Tempat Henti Angkutan Umum Studi Kasus Rute TerboyoPudakpayung, Semarang', Media Komunikasi Teknik Sipil, 14 (3), pp.
287-296.

Kemenhub (2012) Peraturan Menteri Perhubungan Republik Indonesia Nomor PM.10 Tahun 2012 Tentang Standar Pelayanan Minimal Angkutan Massal Berbasis Jalan. Jakarta.

Nurjanah, R., Miro, F. and Nur, I. H. (2015) 'Studi Evaluasi Penempatan dan Pemanfaatan Halte Trans Padang di Koridor I (Pasar Raya-Batas Kota)', JFTSP, 2 (3), p. 70.

Pertiwi, D., Miro, F. and Eriawan, T. (2017) 'Kajian Persepsi Pengguna Terhadap Kualitas Pelayanan Bus Trans Padang dengan Metode Servqual', JFTSP, 2 (3).

$\begin{array}{lr}\text { Fakultas Teknik UMSB } & \text { ISSN 2599-2081 } \\ & \text { EISSN 2599-2090 }\end{array}$

